\title{
Structure of anther heads in some Trifolium L. species
}

\author{
T. KAZIMIERSKI AND E. M. KAZIMIERSKA
}

Institute of Plant Genetics, Polish Academy of Sciences, Poznań

(Received: December 15, 1974.)

\begin{abstract}
The species of the genus Trifolium differ by the number of pollen sacs in stamen heads. Some have only two, other four and in some species there are two, three or four pollen sacs. The opinion of some authors (Schnarf 1931, Davis 1966) that from this point of view this genus is uniform is wrong. There is some dependence between the chromosome number (2n) and the number of pollen sacs. For two species $-T$. carmeli and $T$. desvauxii - the chromosome numbers $2 \mathrm{n}=14$ were established for the first time.
\end{abstract}

\section{INTRODUCTION}

For large taxonomic units the number of pollen sacs in the anther head is considered by embryologists to be stable, and thus constitutes a family trait. In systematic elaborations dealing with the embryology of plants it is claimed that the number of pollen sacs in the anther head is four for most of the families investigated (Davis, 1966; Rutishauser, 1973); families with two pollen sacs in the anther head may also be found (Modilewski, 1953, Davis 1966). There also are families within which some genera have anthers consisting of four, and others of two pollen sacs. In such families the number of pollen sacs in the anther head is a generic characteristic (Modilewski, 1953; Davis, 1966; Schnarf, 1931). Finally species are known in which flowers of one individual have anthers with two and four pollen sacs, e.g. Persea grantissima (Bambocioni-Mezzetti, 1937), Cucumis sativus (Davis, 1966).

According to Davis (1966) and Schnarf (1931), the number of pollen sacs in the anther head in the family Papilionaceae, to which the genus Trifolium belongs, is four. Bijok and Góral (1970) also report 4 pollen sacs in the anthers for the di- and tetraploid forms of white, red and alsike clover which they investigated.

A number of species belonging to the particular genera of Papilionaceae have no doubt four pollen sacs in the anther head. Trifolium, as shown by our investiga- 
tions, includes species with two and four pollen sacs. The structure of the anther heads in the examined Trifolium species and the relation between this trait and the chromosome number as well as the genetic relationship of this species are described.

\section{MATERIAL AND METHODS}

The material for the present study - flower buds - was collected from 17 species and 7 interspecific clover hybrids. The examined T. repens plants belonged to native and foreign populations. The populations from Poland originated from 5 localities in various regions of Poland (fig. 1); foreign populations were represented by forms from Bulgaria (Rodopy, Smolen), Israel (environs of Tel Aviv) and Italy (Botanical garden in Bologna).

$T$. pratense plants from which material for study was taken originate from the same regions of Poland (fig. 1) as those of T. repens.

The species $T$. hybridum is represented by five native populations collected in various parts of Poland (fig. 1).

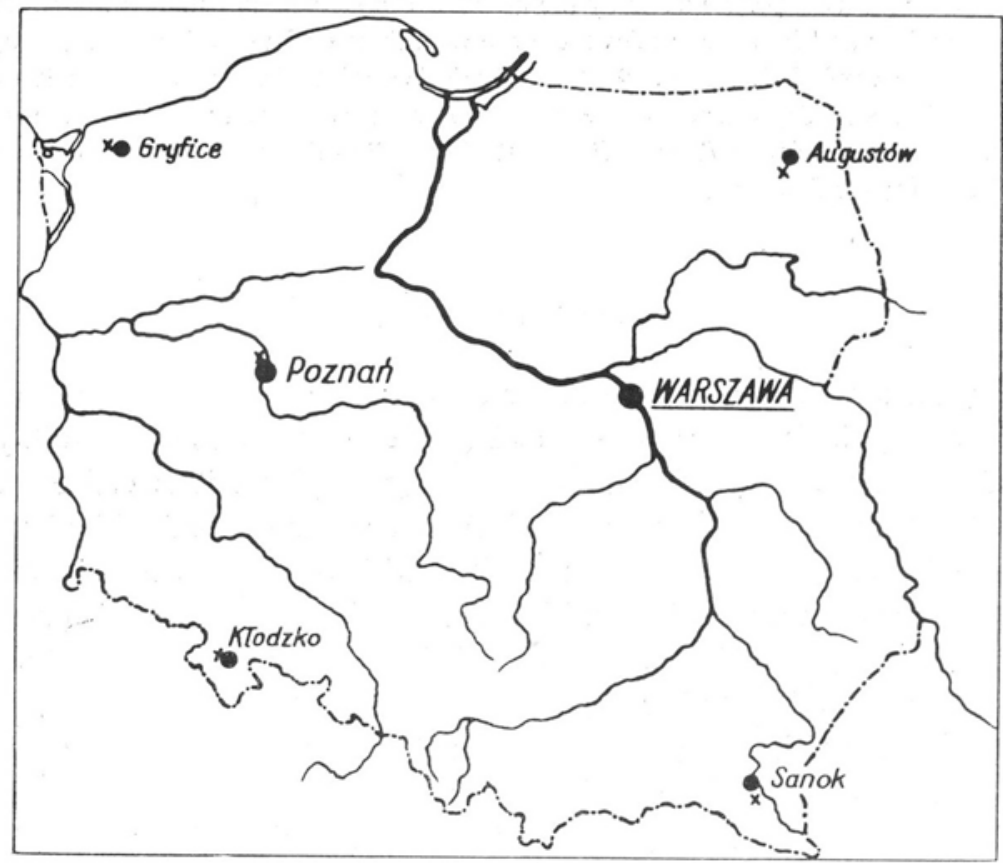

Fig. 1. Districts (•) and localities (x) in Poland from which Trifolium hybridum, T. repens and T. pratense were investigated

The remaining species were received from the Institute of Genetics and Plant Breeding in Sofia (Bulgaria), the Institute in Gatersleben (GDR), Institute of Plant Industry in Leningrad (U. S. S. R.) and the Botanical Gardens in Coimbra (Portugal), Padua (Italy), Gödöllö (Hungary) and Paris (France). 

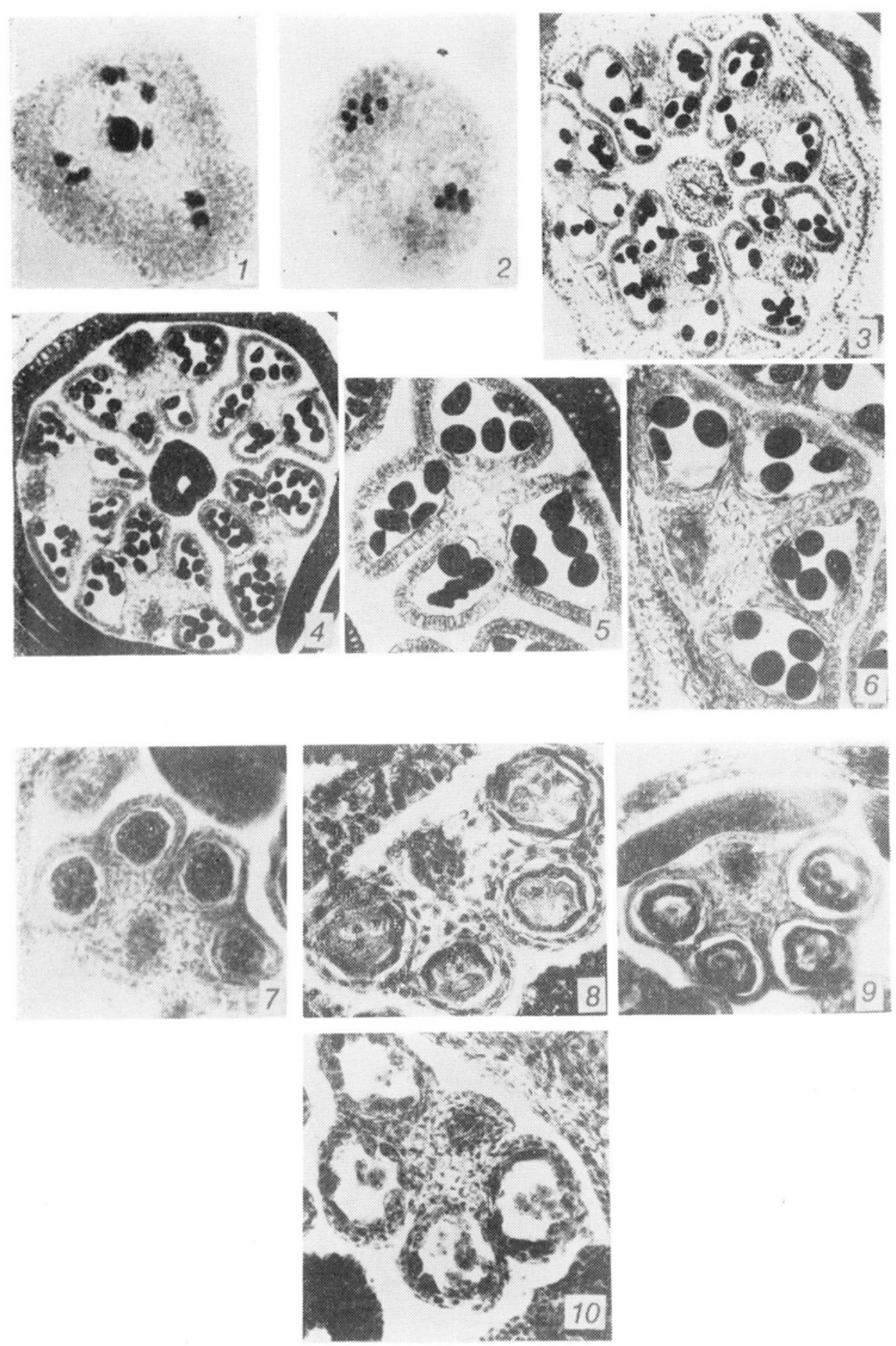

Photos. 1-10. Meiosis in PMC's and cross-sections of the anther heads in Trifolium species $1-T$. carmeli, diakinesis, $7_{\mathrm{II}} ; 2-T$. desavuxii, second metaphase, seven chromosomes in two groups; 3 - 10 - cross sections of the flower buds and anther heads of the species with four pollen sacs in the anther head: $3-T$. purpureum; $4-5-T$. carmeli; $6-T$. desrauxii; $7-T$. hybridum; $8-T$. medium; 9-T. pratense; 10. T. apertum. (enl.: Photos 

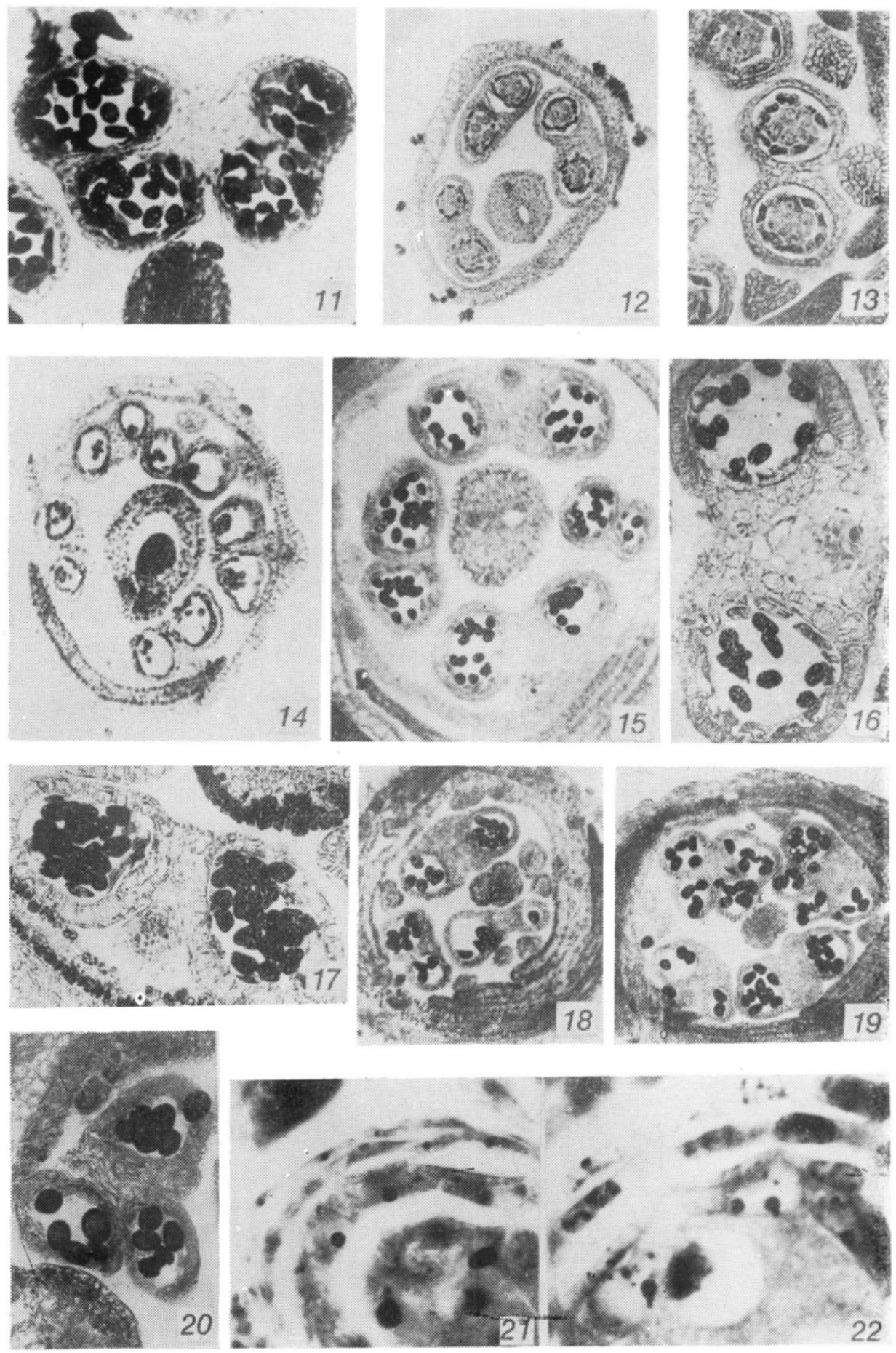

Photos. 11-22. Cross section of the anther heads in Trifolium species

$11-T$. tumens with four pollen sacs in anther head; $12-17$ - species with two pollen sacs in anther head: $12-T$ isthomo carpum; $13-T$. nigrescens; $14-T$. repens; $15-16-F_{1} T$. isthomocarpum $\times T$. nigrescens; $17-F_{1} T$. repens

$T$. nigrescens; $18-20-$ species with an unstable number of pollen sacs in anther head: $18-T$. neglectum; $19-20$ - T. resupinatum; $21-22$ - fragment of the anther wall: $21-T$. neglectum, the anther wall constructed with three of cells layer, the tapetal cells with one nucleus and one nucleolus; $22-T$. medium, the anther wall with three cells layers the tapetal cells with one nucleus and two nucleoli. (enl: Potos. 11, 13, 16, 17 and 20-10 20; Photos. 12, $14,15,18$ and 19-10 $\times 10$; Photos. 21 and $22-10 \times 95$ 
The flower buds of various sizes were immersed in Carnoy or Navashin solution. Fixed material was kept in 70 per cent alcohol. After embedding in paraffin microtome sections $12 \mu$ thick were prepared. After removal of paraffin the sections were stained with iron haemetoxylin and the cell walls were counterstained with fast green and sealed in Canada balsam. The chromosome number in two of the species investigated was determined on smears of microsporogenic cells stained with acetocarmine.

\section{RESULTS}

Chromosome number. In two of the investigated species $-T$. carmeli and $T$. desvauxii, in which the chromosome number was unknown, determination was achieved by analysing the process of meiosis in pollen mother cells. In the analysed cells of $T$. carmeli both during diakinesis (photo 1) and first metaphase, 7 bivalents were found. At the stage of first and second anaphase 7 chromosomes moved to each of the spindle poles. This, during meiosis 7 chromosomes moved to the forming daughter nuclei. This number is by one half smaller than in somatic cells, thus this species has $2 \mathrm{n}=14$ chromosomes.

In each pollen mother cell of the second of the above named species, $T$. desavauxii, there are at the stage of first metaphase 7 bivalents, and the nuclei formed after meiosis (photo 2, fig. 2), have 7 chromosomes in the microspores. In the somatic cells this number corresponds to $2 \mathrm{n}=14$ chromosomes.

Fig. 2. Trifolium desvauxii, second metaphase in P. M. C., two groups with 7 chromosomes.

Magn.: $10 \times 95$

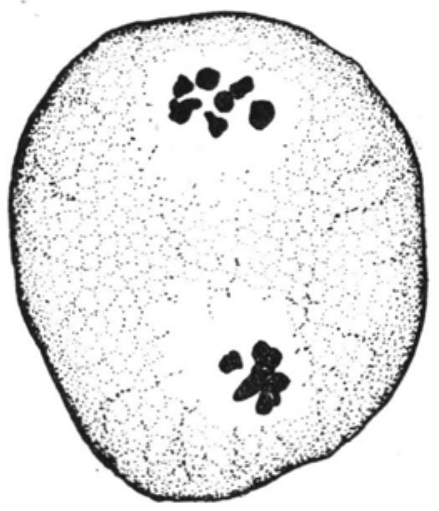

Anther structure. The results for the species investigated and the interspecific hybrids are listed in table 1 . According to the number of pollen sacs and the constancy of this number in the anther head the species enumerated in this table may be divided into three groups:

Group I comprises 11 species and 3 interspecific hybrids. It is characterized by ant her heads formed of 4 pollen sacs in all the plants (photos 3-11).

Group II to which 3 species and 3 interspecific hybrids (obtained by intercrossing the species of this group) belong have anther heads consisting of 2 pollen sacs (photos 12-17). 
For group III including 3 species and one hybrid characteristic is a changing number of pollen sacs in the anther head. In all the plants of this group the number of pollen sacs within each analysed flower is 2,3 , or 4 (photos $18-20$ ). Thus, the species in this group exhibit a high variability within one flower in the number of pollen sacs in the anther heads.

Table 1

Investigated species and hybrids of the Trifolium genus

\begin{tabular}{|c|c|c|}
\hline Species & $\begin{array}{l}\text { Chromosome } \\
\text { number } 2 \mathrm{n}\end{array}$ & $\begin{array}{c}\text { Pollen sacs } \\
\text { number in the } \\
\text { anther }\end{array}$ \\
\hline 1. $T$. alexandrinum & 16 & 4 \\
\hline 2. T. apertum & 16 & 4 \\
\hline 3. T. carmeli & 14 & 4 \\
\hline 4. $T$. desvauxii & 14 & 4 \\
\hline 5. T. hybridum & 16 & 4 \\
\hline 6. T. medium & 80 & 4 \\
\hline 7. T. Michelianum & 16 & 4 \\
\hline 8. $T$. pratense & 14 & 4 \\
\hline 9. T. purpureum & 14 & 4 \\
\hline 10. T. tumens & 16 & 4 \\
\hline 11. T. vavilovii & 16 & 4 \\
\hline $\begin{array}{c}\text { 12. } F_{1} T \text {. alexandrinum } \times T \text {. } \\
\text { vavilovii }\end{array}$ & 16 & 4 \\
\hline $\begin{array}{l}\text { 13. } F_{1} T . \text { apertum } \times T \\
\text { alexandrinum }\end{array}$ & 16 & 4 \\
\hline $\begin{array}{l}\text { 14. } F_{1} T . \text { apertum } \times T . \\
\text { vavilovii }\end{array}$ & 16 & 4 \\
\hline 15. T. isthomocarpum & 16 & 2 \\
\hline 16. T. nigrescens & 16 & 2 \\
\hline 17. $T$. repens & 32 & 2 \\
\hline $\begin{array}{l}\text { 18. } F_{1} T . \text { isthomocarpum } \times \\
T . \text { nigrescens }\end{array}$ & 16 & 2 \\
\hline $\begin{array}{l}\text { 19. } F_{1} T . \text { repens } \times T . \\
\text { isthomocarpum }\end{array}$ & 24 & 2 \\
\hline $\begin{array}{l}\text { 20. } F_{1} T . \text { repens } \times T . \\
\text { nigrescens }\end{array}$ & 24 & 2 \\
\hline 21. T. fragiferum & 16 & - $2,3,4$ \\
\hline 22. T. neglectum & 16 & $2,3,4$ \\
\hline 23. $T$. resupinatum & 16 & $2,3,4$ \\
\hline $\begin{array}{l}\text { 24. } F_{1} T . \text { neglectum } \times T . \\
\text { fragiferum }\end{array}$ & 16 & $2,3,4$ \\
\hline
\end{tabular}

If we consider the number of pollen sacs in the anther head in the aspect of appurtenance to various subgenera into which the genus Trifolium is divided (Trifoliastrum Ser. and Lagopus Bernh.), it is seen (table 2) that this trait is constant for the investigated species of the subgenus Lagopus. All species belonging to this subgenus have anther heads formed of 4 pollen sacs. 
Table 2

Appurtenance of the investigated Trifolium species to the subgenus and sections (division after Bobrov, 1947)

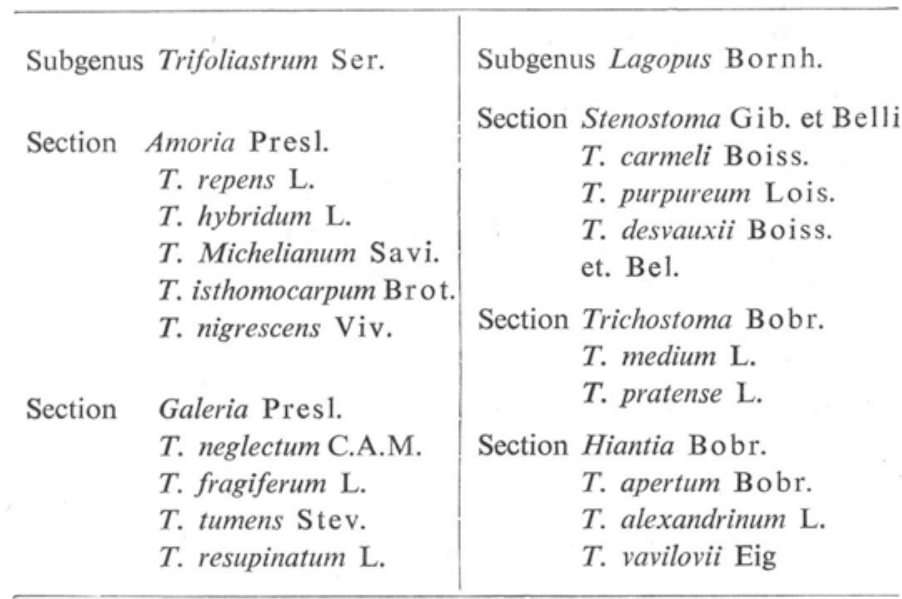

The situation if different in the second subgenus - Trifoliastrum - the species of which belong to two sections: Amoria and Galeria. Of the 5 species of the section Amoria three have anther heads consisting of 2 pollen sacs (T. repens, $T$. nigrescens, T. isthomocarpum) and two have 4 sacs in the anther head (T. hybridum and T. michelianum).

The section Galeria of the subgenus Trifoliastrum shows a different kind of variability. From among the 4 species examined in this section only the plants of T. tumens have anther heads with 4 pollen sacs in all the flowers. In the 3 remaining species $T$. fragiferum, $T$. neglectum and T. resupinatum, each of the examined flowers has anthers formed of 2,3 and 4 pollen sacs (table 3, photos 18-20), these sacs differing in lenght and volume (fig. 3). In two-sac anthers one sac is frequently longer and the other shorter. In three-sac anthers two sacs are equal and one is shorter (fig. 3); in four-sac ones two are longer and two shorter (fig. 3). From among the 3 sacs in three-sac anthers one is of smaller diameter than the remaining ones; in four-sac anthers usually two sacs are of smaller diameter. Such differences were not found in species with only two- or four-sac anther heads. The sacs in the anthers of the latter species do not differ either in length or volume.

Table 3

Number of pollen sacs in the anther of $T$. fragiferum, $T$. neglectum and $T$. resupinatum

\begin{tabular}{l|r|r|c|c|c}
\hline \multirow{2}{*}{ Species } & \multicolumn{2}{|c|}{ Number of pollen } & $\begin{array}{c}\text { Number of } \\
\text { analysed } \\
\text { sacs in the anther: }\end{array}$ & $\begin{array}{c}\text { Number of } \\
\text { analysed } \\
\text { plants }\end{array}$ \\
\cline { 2 - 5 } & \multicolumn{1}{|c|}{2} & \multicolumn{1}{c}{3} & 4 & anthers & fragiferum \\
\hline T. neglectum & 80 & 59 & 61 & 200 & 5 \\
T. resupinatum & 319 & 69 & 70 & 190 & 6 \\
\hline
\end{tabular}



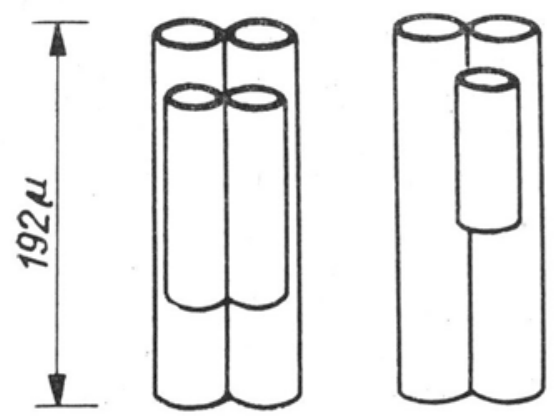

Fig. 3. The anther's structure in Trifolium resupinatum: left - anther with four pollen sacs, right with three pollen sacs

$F_{1}$ crosses have the same number of pollen sacs in the anther head as the parental species. Thus crosses of plants with two- and four-sac anthers have anthers with the corresponding number of sacs (photos 15-17, table 1). From crosses between species with different numbers of pollen sacs in the anther head, such as T. neglectum and $T$. fragiferum, $\mathrm{F}_{1}$ plants exhibited a pollen sac number varying between two and four (table 1).

All the species studied have anther walls consisting of three cell layers under which is a tapetal layer surrounding the sporogenic chamber (photos 21 and 22). Tapetal cells are monuclear and, with the exception of $T$. medium, they have one nucleolus (photo 21). In the cell nuclei of the tapetal layer in the anther of T. medium there is more than one nucleolus (photo 22).

\section{DISCUSSION}

In known cytoembryological studies performed on some Trifolium species precise data are seldom found on the number of pollen sacs in the anther head, only descriptions of the course of microsporogenesis, development of the embryo sac and embryogenesis are given (Mackiewicz T., 1965, 1970; Tschaikina 1957, 1958; Grala, 1964; Poliakova 1958; Fedortschuk, 1944, Bijok, Góral and Góral, 1970a, b; Bijok and Góral, 1970; Krupko, 1971, 1972). In descriptions of the anatomical and histological structure of the anther head mention is made that the anthers have four chambers, without including any photographs or drawings illustrating the cross section of an anther head (Bijok, Góral and Góral 1970a and b; Bijok and Góral 1970). Precise data supplemented with illustrations, concerning the structure of the anther head in T. pratense are given by Hindmarsch (1964); Kazimierski, Kazimierska and Strzyżewska (1973) and Strzyżewska (1973), and for T. hybridum and T. repens by Kazimierski, Kazimierska and Strzyżewska (1973). It results from the above quoted papers that the anther head in $T$. pratense and $T$. hybridum consists of four, and in T. repens of two pollen sacs.

The present studies aiming at establishment of the number of pollen sacs in $T$. pratense, $T$. hybridum and T. repens were performed for each species on 5 populations from vaiious regions of Poland and on forms from other countries. In none of the studied native or foreign populations were deviations in the number of pollen sacs in 
the anther head found. This number was four pollen sacs for $T$. pratense and $T$. hybridum, and two for $T$. repens. It should be mentioned here that the number of pollen sacs in the anther head does not change under the action of some pathogenic factors, e. g. mycoplasm (Kazimierski, Kazimierska and Strzyżewska 1973).

In the aspect of the number of pollen sacs in the anther head, the investigated species and hybrids may be divided into three groups: 1 . with four-sac anthers, 2 . with two-sac anthers and 3. with a varying number of pollen sacs in the pollen head between two and four. Interspecific crosses are characterized by the same number of pollen sacs as the parent species. Species with a varying number of pollen sacs in the pollen head produce hybrids with an also varying number of pollen sacs.

Of the forms examined noteworthy are the species of the section Galeria. From among the four species in this section, only $T$. tumens, has a constant number of pollen sacs amounting to four in the anther head. The remaining species, $T$. fragiferum, $T$. neglectum and $T$. resupinatum, have a varying number of pollen sacs within each flower. Moreover, in these three species not only the number of pollen sacs is variable in the anther head, but also their length and diameter.

The taxonomic work of G. L. Davis based on an extensive literature review and devoted to the embryology of angiosperms also contains data on the structure of the anther heads. It would result from this work that the phenomenon of a variable number of pollen sacs in the anther head is not common. Different numbers of pollen sacs were so far found in Persea grantissima (Bambocioni-Mozzetti, 1937) and in Cucumis sativus (Davis, 1966). The genus Trifolium which includes species with a variable number of pollen sacs is the third taxonomic unit exhibiting this kind of variability.

If we consider the species with a variable number of pollen sacs in the anther head from the aspect of their appurtenance to one of the two subgenera into which this genus is divided (Bobrov, 1947), it is seen that all the studied species of the subgenus Lagopus have a constant number of pollen sacs amounting to four. The species of the second subgenus, Trifoliastrum differ from one another in this trait, some having two, others four and some even 2, 3 and 4 pollen sacs in the anther head. Thus, as far as the number of pollen sacs is to be a characteristic of a given group of species, the studies performed indicate that it is constant in the subgenus Lagopus and variable in the subgenus Trifoliastrum.

The investigations seem also to indicate a relation, though not very strict, between the chromosome number $(2 n)$ of the species and the number of pollen sacs in the anther head. The species examined with chromosome number $2 n=14$ contain in the anther 4 pollen sacs, those with chromosome number $2 n=16$ and numbers being multiples of 16 may have anther heads with two, four and 2, 3 and 4 pollen sacs in the anther head.

As regards the relations between the chromosome number (2n) the number of pollen sacs in the anther head and the crossing of species, the investigations up to date indicate that hybrids can by obtained from the species with a $2 n=16$ chromosome number or its multiple (Kazimierski, Kazimierska and Strzyżewska, 
1972) with an equal number of pollen sacs in the anther head as the parent species. Crosses between species with a $2 n=14$ chromosome number or between species with chromosome numbers $2 \mathrm{n}=14$ and $2 \mathrm{n}=16$ are not known.

\section{CONCLUSIONS}

1. Of the 17 Trifolium species examined eleven have four-sac, three two-sac and three two-, three- and four-sac anther heads.

2. Interspecific hybrids, seven of which were studied, have the same number of pollen sacs in the anthers as the parent species.

3. The investigated species of the subgenus Lagopus have four-sac anther heads, and those of the subgenus Trifoliastrum exhibit two and four pollen sacs. There also are species in which within one flower the anthers may contain 2, 3, or 4 pollen sacs.

4. There is a certain relation between the chromosome number of the species ( $2 n)$ and the number of pollen sacs in the anther haed. Species with $2 \mathrm{n}=14$ chromosomes have 4 pollen sacs in the anther head, and species with $2 n=16$ chromosomes or their multiple have anther heads consisting of two or four or else 2, 3 and 4 pollen sacs.

5. A certain relation is also noticeable between the chromosome number in the genome, the number of pollen sacs in the anther head and the crossing of species. Hybrids were obtained between the species with chromosome number $2 n=16$ and its multiple and an equal number of pollen sacs in the head.

6. In meiosis in the pollen mother cells of $T$. carmeli and $T$. desvauxii there are 7 bivalents, and in somatic cells of these species the chromosome number is $2 \mathrm{n}=14$.

\section{REFERENCES}

Bambocioni-Mozzetti V., 1937. Gimnoovulia in Persea grantissima e considerazioni sulla monomeria del pistillo di questa pianta, Ann. di Bot. (Roma), 21:1-7.

Bijok K., Góral S., 1970. Studia cyto-embriologiczne di- i tetraploidalnych form Trifolium pratense L. var. spontaneum Willk. Acta Agrobotanica 23:367-386.

Bijok K., Góral M., and Góral S., 1970a, Studia embriologiczne nad poliploidalnymi formami Trifolium repens L., Acta Agrobotanica 23:259-277.

Bijok K., Góral M., and Góral S., 1970b, Badania embriologiczne di- i tetraploidalnych form Trifolium hybridum L., Acta Agrobotanica, 23: 279-295.

Bobrov E. G., 1947. The clovers of the USSR. Acta Inst. Bot. Nom. V. L. Komarovii Acad. Sc. URSS. Ser. I, Fasc. 6:164-336 (In Russian with English summary).

Davis G. L., 1966. Systematic Embryology of the Angiosperms. John Willey and Sons, INC. New York London Sydney, pp. 528.

Hindmarsh G. J., 1964. Gametophyte development in Trifolium pratense. Austr. J. Bot. 12:1-14. Grala T., 1964. Megasporogeneza, rozwój woreczka zalążkowego i wczesnych stadiów zarodka u Trifolium repens, var. Ladino. Pozn. Tow. Przyj. Nauk. Prace Komisji Biologicznej 29:3-20. Fedortschuk V. F., 1944, Razvitiie i stroieniie siemiapochki i siemieni u krasnogo klieviera, Trifolium pratense L. Trudy Mosk. Oridena Lenina Akademii Sielskokhoz. Nauk. K. A., Timiryazieva 25:1-39. 
Kazimierski T., Kazimierska E. M. and Strzyżewska Cz., 1972. Species crossing in the genus Trifolium L., Genetica Polonica 13:11-32.

Kazimierski I., Kazimierska E. M., Strzyżewska Cz., 1973. Cytological researches on the cause of plant sterility combined with symptoms of flower greening in three species of clover, Genetica Polonica, 14:399-413.

Krupko S., 1971/72. Embryological and caryological observations on two selected English varieties of white clover, "S 148" and "Kersey", sown in the Poznań province, Bull. de la Soc. des Amis des Sc. et Lettres de Poznań, Sér. D. 12/13:169-180.

Mackiewicz T., 1965. Low seed setting in tetraploid red clover (Trifolium pratense L.) in the light of cytoembryologic analysis, Genetica Polonica 6:6-39.

Mackiewicz T., 1970, Microsporogenesis and heterochromatin grains in octoploid Trifoliuim repens L., Genetica Polonica 11:37-44.

Modilevskij J. S., 1953, Embriologiya pokrytosiemiennych rastienii, Kijev, p. p. 224.

Poljakova T. F., 1958. Razvitie muzhkogo gamietofita u Trifolium pratense. 1. Izmienienija viegietativnogo jadra i obrazovanie gienierativnoi kletki. Viestnik Leningradskogo Univiersitieta, 3:63-76.

Rutishauser A., 1973. Embriologia i biologia Rozmnażania Roślin okrytonasiennych. PWRiL, Warszawa, p. p. 244 (translation).

Schnarf K., 1931, Vergleichende Embryologie der Angiospermen, Berlin.

Strzyżewska Cz., 1973. Chów siostrzany u Trifolium pratense L., Poznań, (unpubl.).

Tschaikina K. V., 1957. Embriologicheskoje izuczeniie novogo vida klieviera Trifolium apertum Bobr., Sbornik rabot kafiedry Botaniki Mosk. Ord. Lenina Sielskokhoz. Akad. im. K. A. Timiryazieva, 1-15.

Tschaikina K. V., 1958. Niekotoryje dannyie po embriologii klieviera apertum (Trifolium apertum Bobr.), Sbornik rabot kafiedry Botaniki Mosk. Ord. Lenina Sielskokhoz. Akad.. K. A. Timiryazieva, 216-226.

Authors' address

Doc. dr Tadeusz Kazimierski

Dr Ewa Kazimierska

Department of Plant Genetics

Polish Academy of Sciences

Strzeszyniska Str. $2 / 4$

60-479 Poznań, Poland

\section{Budowa glówek pylnikowych u niektórych gatunków Trifolium L.}

\section{Streszczenie}

Przeprowadzone badania liczby worków pyłkowych w główce pylnika u 17 gatunków i 7 mieszańców międzygatunkowych Trifolium wykazały, że rodzaj składa się z gatunków których pylniki są zbudowane $\mathrm{z}$ czterech i dwóch worków pyłkowych oraz gatunków, u których w obrębie kwiatu znajdują się pylniki zbudowane $\mathrm{z}$ dwóch, trzech i czterech worków pyłkowych. Zachodzi pewna zależność między liczbą chromosomów (2n) i liczbą worków pyłkowych w główce pylnika. Gatunki $\mathrm{z}$ liczbą $2 \mathrm{n}=14$ chromosomów mają pylniki $\mathrm{z}$ czterech worków pyłkowych, gatunki z liczbą $2 \mathrm{n}=16$ chromosomów i wielokrotnością 16 mają pylniki zbudowane $\mathrm{z}$ dwóch lub czterech worków pyłkowych oraz z dwóch, trzech i czlerech worków pyłkowych. Liczba chromosomów (2n), worków pyłkowych w główce pylnika i zdolność do krzyżowania się gatunków wykazują pewną zależność. Mieszańce otrzymuje się między gatunkami z liczbą $2 n=16$ lub wielokrotnością 16 chromosomów i taką samą liczbą worków pyłkowych w glówce pylnika.

Dla $T$. carmeli i $T$. aesvauxii określono liczbę chromosomów. Dla obu gatunków wynosi ona $2 \mathrm{n}=14$ chromosomów. 